\title{
Defective Uptake of Basic Amino Acids and L-Cystine by Intestinal Mucosa of Patients with Cystinuria *
}

\author{
C. F. McCarthy, † James L. Borland, Jr., $\$$ Harold J. Lynch, Jr., \\ Edward E. Owen, and Malcolm P. Tyor \\ (From the Department of Medicine, Duke University Medical Center, Durham, N. C.)
}

Although the important clinical manifestations of cystinuria may be attributed to diminished renal tubular reabsorption of filtered cystine, the basic amino acids, lysine, arginine, and ornithine, are also excreted in urine in greatly increased quantities (1-3). The high renal clearance of these amino acids is generally believed to be related to a genetically determined defect of a specific tubular reabsorptive system that combines with and reabsorbs these amino acids from tubular fluid (1, 4-6). In addition to the widely recognized abnormality of renal amino acid transport, Milne, Asatoor, Edwards, and Loughridge (7) have suggested that patients with cystinuria may also have a similar defect involving the mucosa of the small intestine. This possibility has been supported not only by the finding of free lysine, ornithine ( 7$)$, and arginine (8) and certain of their metabolic by-products in the feces of such patients after the oral administration of these amino acids, but also by the observation that a given dose of L-arginine produces a smaller rise of plasma arginine in cystinuric subjects than in normal controls. In an attempt to evaluate more directly the possibility of an intestinal amino acid transport defect in patients with cystinuria, small intestinal mucosal biopsies from both cystinuric and noncystinuric human subjects have been incubated with a variety of labeled free amino acids. Although the results do not define the precise mechanism responsible for mucosal amino acid accumulation,

* Submitted for publication January 13, 1964 ; accepted March 19, 1964.

Supported in part by grants AM-03255 and A-5093 from the National Institute of Arthritis and Metabolic Diseases and HTS-5369 from the National Heart Institute, Bethesda, Md.

$\dagger$ Present address: Department of Medicine, Royal Infirmary, Bristol, England.

$\ddagger$ Present address: U. S. Naval Hospital, Jacksonville, Fla. they do demonstrate clearly that cystinuric patients have a defect in the intestinal uptake of $\mathrm{S}^{35}$-L-cystine, $\mathrm{C}^{14}$-L-arginine, $\mathrm{C}^{14}$-L-lysine, and $\mathrm{C}^{14}$-DL-ornithine.

\section{Methods}

Mucosal biopsies were obtained from the duodenum of two patients with cystinuria and four noncystinuric hospitalized patients with chronic disorders, and from seven healthy medical students, six males and one female ( $\mathrm{sec}$ appendix for clinical summaries). The cystinuric patients were each hospitalized ${ }^{1}$ on four separate occasions and were studied over a period of 4 months. The remaining patients and normal subjects were evaluated once over the same time period.

Peroral intestinal biopsy and in vitro incubation. All mucosal biopsy specimens were obtained in the morning with the subjects in the postabsorptive state. A hydraulically operated multiple intestinal biopsy tube (9) was inserted under fluoroscopic control until its tip was just proximal to the ligament of Treitz. A roentgenogram was made just before obtaining the first biopsy and upon completion of the last biopsy. Although the position of the tube was altered slightly after each biopsy, all specimens were obtained from the distal part of the third or fourth portion of the duodenum. In most instances, 4 to 12 successive biopsies were obtained from each patient during a single study. The fourth study period of patient J. M. was terminated after his fifth biopsy because of persistent bleeding, which ceased spontaneously within 24 hours. No other complications of the biopsy procedure were observed. At least one biopsy specimen obtained from the cystinuric and control subjects was examined histologically and under the dissecting microscope; all appeared normal. A total of 106 duodenal mucosal specimens was used during the course of these experiments: 39 from the cystinuric patients, 8 from the noncystinuric hospitalized patients, and 59 from the medical students.

All biopsies were flushed through the biopsy tube with $0.15 \mathrm{M} \mathrm{NaCl}$ and delivered into a beaker containing cold ( 2 to $3^{\circ} \mathrm{C}$ ), $0.15 \mathrm{M} \mathrm{NaCl}$ within seconds of its being cut from the intestinal mucosa. As each biopsy was obtained, it was blotted on filter paper and immediately placed in a $25-\mathrm{ml}$ Erlenmeyer flask containing $1 \mathrm{ml}$ of

\footnotetext{
${ }_{1}$ Clinical Research Unit.
} 
TABLE I

Uptake of amino acids by duodenal mucosa of cystinuric and noncystinuric human subjects*

\begin{tabular}{|c|c|c|c|c|c|}
\hline \multirow[b]{2}{*}{ A mino acids } & \multicolumn{2}{|c|}{ Noncystinuric controls $\dagger$} & \multicolumn{2}{|c|}{ Cystinuria } & \multirow[b]{2}{*}{$\mathrm{p} \S$} \\
\hline & & $\begin{array}{l}\text { No. of } \\
\text { exp'ts }\end{array}$ & & $\begin{array}{l}\text { No, of } \\
\text { exp'ts }\end{array}$ & \\
\hline & \multicolumn{2}{|c|}{$\% / 10 \mathrm{mg} W W t \ddagger 1 S D$} & \multicolumn{2}{|c|}{$\% / 10 \mathrm{mg} W W t \ddagger \pm 1 S D$} & \\
\hline $\mathrm{C}^{14}$-L-arginine & $13.57 \pm 7.71$ & 13 & $0.94 \pm 0.50$ & 8 & $<0.01$ \\
\hline $\mathrm{C}^{14}$-L-lysine & $6.75 \pm 1.47$ & 8 & $0.96 \pm 0.21$ & 5 & $<0.01$ \\
\hline $\mathrm{C}^{14}$-DL-ornithine & $5.60 \pm 3.65$ & 6 & $0.86 \pm 0.11$ & 4 & $<0.10$ \\
\hline $\mathrm{S}^{35}$-L-cystine & $6.44 \pm 1.92$ & 11 & $0.69 \pm 0.26$ & 4 & $<0.02$ \\
\hline$C^{14}$-DL-leucine & $12.01 \pm 6.56$ & 4 & $13.01 \pm 6.69$ & 6 & $>0.50$ \\
\hline $\mathrm{C}^{14}$-L-phenylalanine & $13.55 \pm 1.85$ & 4 & 12.31 & 1 & \\
\hline$C^{14}$-DL-cystine & $13.76 \pm 1.61$ & 7 & $11.24 \pm 9.75$ & 8 & $>0.30$ \\
\hline
\end{tabular}

* Each reaction flask contained $1 \mathrm{ml}$ of calcium-free Krebs-Ringer phosphate buffer ( $\mathrm{pH}$ 7.4) and the appropriate $\mathrm{C}^{14}$ - or $\mathrm{S}^{35}$-labeled amino acid, $10^{-4} \mathrm{M}, 40,000$ to $400,000 \mathrm{cpm}$. Incubation time was 30 minutes.

$\dagger$ Values listed represent the averages obtained from all noncystinuric subjects.

$\%$ \% $10 \mathrm{mg} \mathrm{WWt}=[\mathrm{cpm} / 10 \mathrm{mg}$ wet weight tissue $(\mathrm{WWt}) / \mathrm{cpm} / \mathrm{ml}$ incubating fluid $] \times 100$

$\$$ With the exception of $\mathrm{C}^{14}$-DL-leucine, the large differences in variation between the two groups preclude the meaningful use of the standard $t$ test. Therefore, $\mathrm{p}$ values were computed by the approximate solution to the Behrens-Fisher problem (11).

previously oxygenated calcium-free Krebs-Ringer phosphate buffer ( $\mathrm{pH} 7.4$ ), and the appropriate $\mathrm{C}^{14}$ - or $\mathrm{S}^{35}$ labeled amino acid, final concentration $10^{-4} \mathrm{M}, 40,000$ to $400,000 \mathrm{cpm}$. The flasks were stoppered, and incubation was effected in a shaking water bath at $37^{\circ} \mathrm{C}$ for $30 \mathrm{~min}$ utes. This incubation time was selected because preliminary experiments indicated that the mucosal uptake of $\mathrm{C}^{\mathbf{1 4}}$-L-arginine $\left(10^{-4} \mathrm{M}\right)$ tended to plateau after a 20 to 30 -minute period of incubation in both normal and cystinuric subjects. The time interval between the procurement of the biopsy and the onset of incubation averaged approximately 2 minutes. The labeled amino acids used included uniformly labeled $\mathrm{C}^{\mathbf{1 4}}$-L-arginine and $\mathrm{C}^{14}$-L-lysine, ${ }^{2} \mathrm{C}^{14}$-DL-ornithine-5, ${ }^{2} \mathrm{C}^{14}$-DL-leucine-1, ${ }^{2} \mathrm{C}^{14}$-Lphenylalanine-1,2 and $\mathrm{S}^{35}$-L-cystine. ${ }^{3}$ Corresponding unlabeled L-amino acids were used: L-cystine and L-arginine, ${ }^{4}$ L-lysine and L-ornithine, ${ }^{5}$ and L-leucine and L-phenylalanine. ${ }^{6}$

Preparation of tissue and measurement of radioactivity. Immediately after completion of incubation, the tissue was removed from each flask, washed briefly in KrebsRinger phosphate buffer containing the appropriate unlabeled L-amino acid, $10^{-4} \mathrm{M}$, blotted on filter paper, and then weighed on a torsion balance. ${ }^{7}$ The tissue (wet weight, 5 to $20 \mathrm{mg}$ per reaction vessel) was then placed in a ground glass homogenizer containing $1 \mathrm{ml}$ of $0.15 \mathrm{M}$ $\mathrm{NaCl}$. After thorough homogenization, the contents of each flask were quantitatively transferred to a test tube, and the protein was precipitated by the addition of 0.1 $\mathrm{ml}$ of $50 \%$ trichloroacetic acid (TCA). After a 10-

2 New England Nuclear Corp., Boston, Mass.

3 The Radio Chemical Centre, Amersham, England.

4 Mann Research Laboratories, New York, N. Y.

5 California Corporation for Biochemical Research, Los Angeles, Calif.

6 Sigma Chemical Co., St. Louis, Mo.

${ }^{7}$ F. P. E. Precision Balance, Federal Pacific Electric Co., Newark, N. J. minute period of centrifugation at $20,000 \mathrm{rpm}, 0.5 \mathrm{ml}$ of the supernatant fluid was transferred to a standard $20-\mathrm{ml}$ counting vial. In each instance, $0.1 \mathrm{ml}$ of the final corresponding incubating fluid was transferred to a counting vial. In selected experiments, the TCA precipitate was dissolved in $\mathrm{NaOH}$, and appropriate samples were subsequently counted. The scintillation mixture added to each counting vial consisted of $10 \mathrm{ml}$ of a solution containing $7.5 \mathrm{ml}$ p-dioxane, $1.25 \mathrm{ml}$ anisole, $1.25 \mathrm{ml}$ dimethoxyethane, $60 \mathrm{mg}$ 2,5-diphenyloxazole, and $1.5 \mathrm{mg}$ 1,4-bis-2-(5-phenyloxazolyl) benzene. Radioactivity was measured with a Packard Tri-Carb liquid scintillation spectrometer. The presence of self-quenching of the two samples was determined by the addition of appropriate amounts of $\mathrm{C}^{14}$ or $\mathrm{S}^{35}$ radioactivity to the supernatant and incubating fluids. Self-quenching amounted to between 11 and $37 \%$ for the supernatant sample and was negligible $( \pm 2 \%)$ when incubating fluid was used. An internal standard was added after the supernatant fluid was counted and correction made for internal quenching.

Calculations of results. Because of the wide variability in mucosal wet weight, all data have been expressed either in terms of the percentage of uptake of labeled amino acid per $10 \mathrm{mg}$ of wet weight of tissue (WWt), or in terms of the ratio (I/O) of total radioactivity between tissue water (TW) and final incubating fluid:

$$
\mathrm{I} / \mathrm{O}=\frac{\mathrm{cpm} / \mathrm{ml} \mathrm{TW}}{\mathrm{cpm} / \mathrm{ml} \text { incubating fluid }} .
$$

In these calculations it has been assumed that tissue water comprises $80 \%$ of the wet weight of mucosal tissue (10).

\section{Results}

Uptake of selected $C^{\mathbf{1 4}}$-labeled amino acids and $S^{35}$-L-cystine by duodenal mucosa from noncy'stinuric human subjects. The average mucosal 
TABLE II

Uptake of basic amino acids and cystine by duodenal mucosa of cystinuric and noncystinuric human subjects*

\begin{tabular}{|c|c|c|c|c|c|c|c|c|c|}
\hline \multirow[b]{2}{*}{ Subjects } & & \multicolumn{2}{|c|}{$\mathrm{C}^{14}$-L-Arginine } & \multicolumn{2}{|c|}{ C14-L.-Lysine $^{14}$} & \multicolumn{2}{|c|}{$\mathrm{Cl}^{14}$-DL-Ornithine } & \multicolumn{2}{|c|}{$\mathrm{S}^{35-L-C y s t i n e}$} \\
\hline & & Tissue uptake & $\mathrm{I} / \mathrm{O} \dagger$ & Tissue uptake & $\mathrm{I} / \mathrm{O}$ & Tissue uptake & $\mathrm{I} / \mathrm{O}$ & Tissue uptake & $\mathrm{I} / \mathrm{O}$ \\
\hline Cystinuria & & $\% / 10 \mathrm{mg} \mathrm{WW} t^{\ddagger}$ & & $\% / 10 \mathrm{mg} \mathrm{WW}$ & & $\%, 10 \mathrm{mg} \mathrm{WW}$ & & $\% / 10 \mathrm{mg} \mathrm{WII}$ & \\
\hline G. G., & No. of ex ${ }_{1}$ ts & 3 & & 2 & & 2 & & 2 & \\
\hline $46 \mathrm{yrs}$ & $\begin{array}{l}\text { Average } \pm 1 \mathrm{SI} \\
\text { Range }\end{array}$ & $\begin{array}{l}0.91 \pm 0.69 \\
0.59-1.70\end{array}$ & $\begin{array}{l}0.75 \pm 0.51 \\
0.47-1.42\end{array}$ & $\begin{array}{l}0.90 \\
0.67-1.12\end{array}$ & $\begin{array}{l}0.72 \\
0.54-0.90\end{array}$ & $\begin{array}{l}0.75 \\
0.74-0.75\end{array}$ & $\begin{array}{l}0.60 \\
0.59-0.60\end{array}$ & $\begin{array}{l}0.56 \\
0.39-0.74\end{array}$ & $\begin{array}{l}0.45 \\
0.31-0.59\end{array}$ \\
\hline $\begin{array}{l}\text { J. M., } \\
54 \text { rs }\end{array}$ & No. of exp'ts & 5 & & 3 & & 2 & & & 2 \\
\hline $\begin{array}{l}54 \text { yrs } \\
\text { Xoncystinuric } \\
\text { controls }\end{array}$ & $\begin{array}{l}\text { Average } \pm 1 \text { SD } \\
\text { Range }\end{array}$ & $\begin{array}{l}0.96 \pm 0.52 \\
0.60-1.67\end{array}$ & $\begin{array}{l}0.77 \pm 0.42 \\
0.48-1.34\end{array}$ & $\begin{array}{l}1.01 \pm 0.20 \\
0.80-1.16\end{array}$ & $\begin{array}{l}0.81 \pm 0.16 \\
0.64-0.93\end{array}$ & $\begin{array}{l}0.95 \\
0.91-1.00\end{array}$ & $\begin{array}{l}0.76 \\
0.73-0.80\end{array}$ & $\begin{array}{l}0.81 \\
0.61-1.01\end{array}$ & $\begin{array}{l}0.65 \\
0.49-0.81\end{array}$ \\
\hline $\begin{array}{l}\text { Medical } \\
\text { students (7), } \\
21-24 \mathrm{yrs}\end{array}$ & $\begin{array}{l}\text { No. of explts } \\
\text { Average } \pm 1 \text { SD } \\
\text { Range }\end{array}$ & $\begin{array}{c}17.87 \pm 6.81 \\
9.42-31.00\end{array}$ & $\begin{array}{r}15.00 \pm 5.40 \\
8.01-25.00\end{array}$ & $\begin{array}{l}7.07 \pm 1.19{ }^{7} \\
5.70-8.57\end{array}$ & $\begin{array}{l}5.94 \pm 0.91 \\
4.93-6.90\end{array}$ & $\begin{array}{l}6.06 \pm 3.85 \\
3.05-12.06\end{array}$ & $\begin{array}{l}5.11 \pm 3.30 \\
2.42-10.21\end{array}$ & $\begin{array}{l}6.44 \pm 1.92 \\
3.95-9.84\end{array}$ & $\begin{array}{l}1 \\
5.31 \pm 1.64 \\
3.23-8.20\end{array}$ \\
\hline $\begin{array}{l}\text { Hospital } \\
\text { patients (4), } \\
18-76 \text { yrs }\end{array}$ & $\begin{array}{l}\text { No. of exp's } \\
\text { Average } \pm 1 \mathrm{SD} \\
\text { Range }\end{array}$ & $\begin{array}{l}8.57 \pm 3.61^{6} \\
5.69-14.57\end{array}$ & $\begin{array}{l}7.20 \pm 3.14 \\
4.60-12.92\end{array}$ & 4.52 & 3.72 & 3.27 & 2.61 & & \\
\hline
\end{tabular}

* Each reaction flask contained $1 \mathrm{ml}$ of calcium-free Krebs-Ringer phosphate buffer ( $\mathrm{pH} 7.4)$ and the appropriate $\mathrm{C}^{14}$-or $\mathrm{S}^{35}$-labeled amino acid, $10^{-4} \mathrm{M}, 40,000$ to $400,000 \mathrm{cpm}$.

$\dagger \mathrm{I} / 0=(\mathrm{cpm} / \mathrm{ml} \mathrm{Tw}) /(\mathrm{cpm} / \mathrm{ml}$ incubating fluid at end of 30 -minute incubation period). Tissue water (TW) was assume 1 to equal $80 \%$ wet weight of intestine (10).

$\ddagger \% / 10 \mathrm{mg} W W \mathrm{t}=[\mathrm{cpm} / 10 \mathrm{mg}$ wet weight tissue $(\mathrm{WWt}) / \mathrm{cpm} / \mathrm{ml}$ incubating fluid $] \times 100$.

uptake of the seven labeled amino acids used in these experiments has been listed in Table I. The average values for the uptake of $\mathrm{S}^{35}$-L-cystine and the $\mathrm{C}^{14}$-labeled basic amino acids are also presented in Table II along with the corresponding radioactivity ratios observed between mucosal tissue water and final incubating fluid. After a 30minute period of incubation, an average of 5 to $10 \%$ of the total radioactivity initially present in the incubating fluid was recovered in the TCA supernatant fluid of mucosal tissue. The TCA precipitate did not contain significant radioactivity, indicating that incorporation of the labeled substrate into protein was negligible during this period of incubation. As indicated in Table $\mathrm{I}$, the mean mucosal uptake of $\mathrm{C}^{14}$-L-arginine, $\mathrm{C}^{14}$-DLleucine, $\mathrm{C}^{14}$-phenylalanine, and $\mathrm{C}^{14}$-DL-cystine was considerably greater than that of $\mathrm{C}^{14}$-L-lysine, $\mathrm{C}^{14}$ DL-ornithine, and $\mathrm{S}^{35}$-L-cystine.

The ability of duodenal mucosa from noncystinuric human subjects to take up the labeled amino acids listed above is perhaps best illustrated by a consideration of the radioactivity present per unit volume of mucosal tissue water (I) relative to that contained in a similar volume of final incubating fluid $(\mathrm{O})$. The $\mathrm{I} / \mathrm{O}$ ratios from $\mathrm{C}^{14}$-Larginine $(11.10 \pm 5.21), \mathrm{C}^{14}$-DL-leucine $(10.41 \pm$ $6.50), \mathrm{C}^{14}$-L-phenylalanine $(11.23 \pm 1.71)$, and $\mathrm{C}^{14}$-DL-cystine $(11.70 \pm 1.11)$ were higher than those obtained for $\mathrm{C}^{14}$-L-lysine $(5.66 \pm .97), \mathrm{C}^{14}$ DL-ornithine $(4.69 \pm 3.35)$, and $\mathrm{S}^{35}$-L-cystine $(5.31 \pm 1.64)$. The $\mathrm{I} / \mathrm{O}$ ratios listed are almost certainly lower than those that actually existed between epithelial cells and surrounding incubating fluid, since the former represented only a fraction of the total tissue used in these experiments. No attempt has been made to quantitatively estimate the actual ratios that may have existed between absorbing cells and incubating fluid. Even if corrections for epithelial mass were possible, the $\mathrm{I} / \mathrm{O}$ ratios obtained would not necessarily provide reliable indexes of the final free amino acid concentration gradient, since the specific activity of the various labeled amino acids in mucosal tissue was not determined. In the present experiments 80 to $93 \%$ of the extracted amino acids would have to be metabolized to produce a free amino acid $\mathrm{I} / \mathrm{O}$ ratio of 1.0 or below.

Although a detailed comparison of mucosal amino acid uptake between healthy student volunteers and hospitalized patients is precluded by the limited number of observations (Table II), the intestinal uptake of $\mathrm{C}^{14}$-L-arginine was significantly lower $(p=<0.01)$ in the group of subjects with chronic illness. The single uptake values for $\mathrm{C}^{14}$-L-lysine and $\mathrm{C}^{14}$-DL-ornithine are also somewhat lower than the average values noted in normal controls. 
The percentage of uptake of labeled amino acids obtained when mucosal tissue from student volunteers was incubated in the presence of potassium cyanide, $10^{-2} \mathrm{M}$, is shown in Table III. A marked depression of uptake of each amino acid used in these particular experiments is apparent (Tables I and III).

Uptake of $C^{14}$-labeled amino acids and $S^{35}-\mathrm{L}-$ cystine by duodenal mucosa from patients with cystinuria. The average and range of uptake of $\mathrm{C}^{14}$-L-arginine, $\mathrm{C}^{14}$-L-lysine, $\mathrm{C}^{14}$-DL-ornithine, and $\mathrm{S}^{35}$-L-cystine by duodenal mucosa from each cystinuric patient have been listed in Table II. The mean mucosal uptake of each amino acid studied has been compared with the corresponding values obtained in noncystinuric controls in Table I. A1though the average mucosal uptake of $\mathrm{C}^{14}$-DL-leucine, $C^{14}$-L-phenylalanine (one value), and $C^{14}$-DLcystine was quite similar in the two groups, the uptake of the remaining amino acids ( $\mathrm{C}^{14}$-L-arginine, $\mathrm{C}^{14}$-L-lysine, $\mathrm{C}^{14}$-DL-ornithine, and $\mathrm{S}^{35}$-L-cystine) by duodenal mucosa from cystinuric subjects was much lower than that noted in noncystinuric controls (Tables I and II). Indeed, the uptake of these four amino acids was quite comparable to the values obtained when normal mucosa was incubated in the presence of potassium cyanide, $10^{-2} \mathrm{M}$ (Tables II and III). The average $\mathrm{I} / \mathrm{O}$ ratio for $\mathrm{S}^{35}$-L-cystine and $\mathrm{C}^{\mathbf{1 4}}$-basic amino acids in patients with cystinuria was uniformly less than 1.0 (Table II). On the other hand, the I/O ratios for $\mathrm{C}^{14}$-DL-leucine (11.88 \pm $6.25), C^{14}-\mathrm{L}-$ phenylalanine (10.54), and $\mathrm{C}^{14}$-DLcystine $(9.17 \pm 7.95)$ did not differ significantly between the two groups.

\section{Discussion}

The in vitro experiments described demonstrate that duodenal mucosa from patients with cystinuria contains a defective uptake system for $\mathrm{S}^{35}$ L-cystine, $\mathrm{C}^{14}$-L-arginine, $\mathrm{C}^{14}$-L-lysine, and $\mathrm{C}^{14}$-DLornithine. The results of previous amino acid clearance studies in patients with this genetic disorder $(1,5,6,11,12)$ and the present finding of similar average mucosal uptake values in both cystinuric and noncystinuric subjects for $\mathrm{C}^{14}$-DL-leucine and $\mathrm{C}^{14}$-L-phenylalanine suggest that this intestinal defect may be largely restricted to these four amino acids. Although the exact nature of
TABLE III

Effect of cyanide* on amino acid uptake by duodenal mucosa of normal human subjects $\dagger$

\begin{tabular}{lc}
\hline \multicolumn{1}{c}{ Amino acids } \\
\hline & $\% / 10 m g W W t \ddagger$ \\
$C^{14}$-L-arginine & 1.41 \\
$C^{14}$-L lysine & 1.24 \\
$C^{14}$-DL-ornithine & 1.32 \\
$\mathrm{~S}^{35}$-L-cystine & 1.36 \\
$\mathrm{C}^{14}$-DL-leucine & 1.74 \\
$\mathrm{C}^{14}$-L-phenylalanine & 1.72 \\
$C^{14}$-DL-cystine & 0.55
\end{tabular}

* Each reacting flask contained $1 \mathrm{ml}$ of calcium-free Krebs-Ringer phosphate buffer (pH 7.4) and the appropriate $\mathrm{C}^{14}$ - or $\mathrm{S}^{35}$-labeled amino acid, $10^{-4} \mathrm{M}, 40,000$ to 400,000 $\mathrm{cpm}$, and potassium cyanide, $10^{-2} \mathrm{M}$. Incubation time was 30 minutes.

$\dagger$ Values listed represent the results of one experiment for each amino acid listed.

$\ddagger \% / 10 \mathrm{mg} W W \mathrm{~W}=[\mathrm{cpm} / 10 \mathrm{mg}$ wet weight tissue (WWt)/cpm/ml incubating fluid] $\times 100$.

the processes concerned with the movement of cystine and basic amino acids across the intestinal wall has not been defined by these uptake studies, the results seem most consistent with a proposal that a defect of intracellular amino acid accumulation by intestinal epithelial cells may be primarily responsible for the impaired intestinal absorption of lysine, ornithine (7), and arginine (8) in patients with cystinuria.

Previous studies designed to assess the mechanism responsible for the intestinal absorption of these amino acids in experimental animals have been limited in number. However, available data have suggested that the basic amino acids in question and L-cystine may be absorbed principally by the operation of an active transport system. Using the everted intestinal loop technique, Hagihira. Lin, Samiy, and Wilson (13) have demonstrated that $\mathrm{C}^{14}$-L-arginine, $\mathrm{C}^{14}$-L-lysine, and $\mathrm{C}^{14}$-DL-ornithine may be transported across the small intestinal wall against a chemical concentration gradient. Neil (14) has independently indicated that L-cystine may also be transferred from mucosal to serosal bathing fluid against a concentration gradient. The possibility that these four amino acids may at least partially share a common intestinal transport system similar to that suggested for kidney has been supported by the observation (13) that the net intestinal transport of $\mathrm{C}^{14}$-L-lysine is inhibited by the addition of L-cystine or L-arginine to mucosal bathing fluid. Additional and more convincing evidence in support of this hypothesis 
may be obtained from the present demonstration of a markedly diminished intestinal uptake of $\mathrm{S}^{35}$-L-cystine, $\mathrm{C}^{14}$-L-arginine, $\mathrm{C}^{14}$-L-lysine, and $\mathrm{C}^{14}$ DL-ornithine in patients with the genetic disorder, cystinuria.

The probable existence of an active mucosal uptake system in noncystinuric subjects for each of the amino acids utilized in the present experiments is indicated by the demonstration of considerably more total radioactivity in mucosal tissue water than in surrounding incubating fluid after a 30-minute period of incubation. As previously mentioned, the I/O ratios listed are almost certainly lower than the ratios that actually existed betwen intestinal epithelial cells and incubating fluid, since epithelial cell mass represented only a fraction of total mucosal tissue used in these experiments. The present analytical procedures estimated radioactivity rather than the actual concentration of free amino acid, however, and the possibility that a portion of the measured radioactivity represented metabolites of the amino acids cannot be excluded. Despite uncertainty regarding the degree to which the extracted amino acids may be metabolized, it seems unlikely that the observed radioactivity ratios (average, 4.7 to 11.7) can be explained entirely on the basis of metabolic transformation. Previous studies (15) in the rat have demonstrated that at least $50 \%$ of the lysine and ornithine taken up by intestinal tissue from incubating fluid can be recovered as free lysine and ornithine in tissue homogenates. This degree of metabolism would not be of sufficient magnitude to reduce the free amino acid radioactivity ratios to values of 1.0 . Thus, at the present time, it would seem most reasonable to suggest that intestinal mucosa from normal human subjects contains a system that is capable of transporting cystine, lysine, arginine, ornithine, leucine,' and phenyalanine into an intestinal epithelial cell against a chemical concentration gradient. If so, a concentration gradient from epithelial cell to submucosal capillary might well be established that would be appropriate for the subsequent diffusion of these various amino acids into venous plasma.

The finding that the total radioactivity ratios between mucosal tissue water and incubating fluid were less than 1.0 in the two patients with cys- tinuria definitely establishes the presence of an abnormal uptake system for $\mathrm{C}^{14}$-L-cystine, $\mathrm{C}^{14}$-Larginine, $\mathrm{C}^{14}$-L-lysine, and $\mathrm{C}^{14}$-DL-ornithine. The magnitude of this defect is perhaps best illustrated by the observation that uptake values comparable to those obtained in patients with cystinuria were noted when mucosal specimens from normal human subjects were incubated in the presence of cyanide, $10^{-2} \mathrm{M}$. At first glance, these findings might suggest the complete absence of an active transport system for these four amino acids in patients with cystinuria. However, as mentioned previously, the observed radioactivity ratios between tissue water and incubating fluid are probably considerably lower than those actually present between intestinal epithelial cells and surrounding fluid. Therefore, the presence of a rudimentary active uptake system for cystine and basic amino acids within the proximal small intestine of cystinuric subjects cannot be excluded. That certain of these amino acids must be at least partially absorbed in vivo is clearly evident from the loading experiments described earlier (8).

In contrast to the overt differences of $\mathrm{S}^{35}$-L-cystine uptake between cystinuric and noncystinuric patients, the average mucosal uptake of $\mathrm{C}^{14}$-DLcystine was quite similar in the two groups. This finding was certainly unanticipated and is difficult to explain. Several factors of possible significance must be considered. First, the specific activities of the D- and L-isomers of $\mathrm{C}^{14}$-cystine were vastly different. Although each comprised approximately $50 \%$ of the total radioactivity $(120,000 \mathrm{cpm})$ in the incubating fluid, the final concentration of D-cystine was $10^{-11} \mathrm{M}$, whereas L-cystine was $10^{-4} \mathrm{M}$. Second, as previously emphasized, the present measurements do not reflect the extent of metabolic transformation of labeled amino acid by the mucosal cell. The degree of metabolism might vary considerably at different amino acid concentrations. Third, there was considerably more variability in the uptake of $\mathrm{C}^{14}$-DL-cystine in patients with cystinuria than in noncystinuric controls. Although the considerations listed above preclude a final explanation for this observation, the presence of an active intestinal uptake system for $C^{14}-D-c y s t i n e$, which is relatively spared in patients with cystinuria, must be considered as a possibility. That $\mathrm{C}^{14}$-D-cystine 
may be concentrated by duodenal mucosa in noncystinuric subjects is perhaps suggested by the observation that the mucosal uptake of $\mathrm{S}^{35}$-L-cystine was only about one-half of that observed with $\mathrm{C}^{14}$ DL-cystine. Since the specific activity of the D-isomer was much greater than that of L-cystine, an active transport system for $\mathrm{C}^{\mathbf{1 4}}$-D-cystine might be apparent from radioactivity measurements even if its capacity was extremely limited. Although not entirely comparable, previous studies (14) in the rat have failed to demonstrate the presence of an active intestinal transport system for $D$-cystine. The present interpretation of the $\mathrm{C}^{14}$-DL-cystine. experiments is also difficult to reconcile with the finding of a significantly lower mucosal uptake of $\mathrm{C}^{14}$-DL-ornithine in patients with cystinuria. It is apparent that additional studies are needed before it may be assumed that an active intestinal uptake system for $\mathrm{C}^{14}$-D-cystine may normally exist and be selectively uninvolved in cystinuria.

The clinical significance of the present observations must obviously remain speculative. Colliss, Levi, and Milne (16) have suggested that the diminished absorption of the essential amino acid lysine might be responsible for the somewhat reduced height of patients with cystinuria. The observation that patients with chronic disease exhibit significantly less mucosal uptake of $\mathrm{C}^{14}$-Larginine than do young healthy student volunteers deserves further evaluation, since this finding might also be of importance particularly if other amino acids are subsequently shown to be involved. That this consideration may be more applicable to patients with intestinal disorders is perhaps suggested by the fact that diarrhea was the major complaint of three of the four patients in the chronic disease group (see Appendix). Finally, if the present in vitro data reflect the degree of depression of L-cystine absorption in vivo, it would seem unreasonable to expect the development of therapeutically important inhibitors of cystine absorption.

\section{Summary}

1) The uptake of $C^{14}$-L-arginine, $C^{14}-L$-lysine, $\mathrm{C}^{14}$-DL-ornithine, $\mathrm{S}^{35}$-L-cystine, $\mathrm{C}^{14}$-DL-leucine, $\mathrm{C}^{14}$ L-phenylalanine, and $\mathrm{C}^{14}$-DL-cystine by duodenal mucosa from two cystinuric patients and eleven noncystinuric controls has been determined.
2) Duodenal mucosa from noncystinuric subjects was found to concentrate each of the labeled amino acids used in these experiments. For all labeled amino acids, the average radioactivity ratios between mucosal tissue water and tissue incubating fluid ranged between 4.7 and 11.7.

3) The uptake of $C^{14}$-L-arginine, $C^{14}$-L-lysine, $\mathrm{C}^{14}$-DL-ornithine, and $\mathrm{S}^{35}$-L-cystine by duodenal mucosa from cystinuric patients was consistently lower than corresponding values obtained in noncystinuric controls. For these amino acids, the average radioactivity ratio between mucosal tissue water and incubating fluid at the end of the experiment was uniformly less than 1.0. In contrast, the average mucosal uptake and radioactivity ratios for $\mathrm{C}^{14}$-DL-leucine, $\mathrm{C}^{14}$-L-phenylalanine, and $\mathrm{C}^{14}$-DL-cystine did not differ significantly between the two groups.

4) These experiments demonstrate clearly the presence of a selective defect of intracellular amino acid accumulation by intestinal mucosa of patients with cystinuria. They also indicate that intestinal epithelial cells from normal human subjects may accumulate arginine, lysine, cystine, ornithine, leucine, and phenylalanine against a concentration gradient.

\section{Appendix}

Cystinuria. The first subject (G. G.) was a 46-yearold white male who became symptomatic at age 26 when a left nephrectomy was necessitated because of hydronephrosis and renal stones. Since then, he has had intermittent bouts of renal colic and hematuria. On two occasions stones (composed almost entirely of cystine) have been removed from the right kidney. During the present studies, laboratory investigations disclosed normal hematological values, a blood urea nitrogen (BUN) of $25 \mathrm{mg}$ per $100 \mathrm{ml}$, and an inulin clearance of $31 \mathrm{ml}$ per minute. Measurement of the 24-hour excretion rate of free amino acids demonstrated the presence of excessive amounts of cystine $(1,304 \mathrm{mg})$, lysine $(568 \mathrm{mg})$, and arginine ( $469 \mathrm{mg}$ ). The second subject (J. M.) was a 54-year-old white male who began having episodes of renal colic at age 23. Subsequently, he has had a right nephrectomy for "pyelonephrosis" and at least two other surgical procedures for removal of cystine stones from the left kidney. Laboratory data obtained during the course of the present investigation included a normal hemogram and urinalysis, a BUN of $29 \%$, and an inulin clearance of $52 \mathrm{ml}$ per minute. As in the first subject, abnormal 24-hour excretion values for cystine $(1,035$ $\mathrm{mg}$ ), lysine (158 $\mathrm{mg}$ ), ornithine $(259 \mathrm{mg})$, and arginine $(273 \mathrm{mg}$ ) were obtained. 
Noncystinuric hospitalized patients. 1) M. A., 30 years, white, female: diagnosis, diabetes mellitus, "diabetic diarrhea"; 2) J. S., 19 years, Negro, female: diagnosis, sarcoidosis involving uveal tract and hilar lymph nodes; 3) C. A., 62 years, white, male: diagnosis, diarrhea of undetermined origin; and 4) W. C., 57 years, white, male : diagnosis, postgastrectomy malnutrition with diarrhea.

\section{Addendum}

Since submission of this manuscript, a defect in the uptake of $\mathrm{C}^{14}$-L-lysine and $\mathrm{S}^{35}$-L-cystine by intestinal mucosa obtained from cystinuric patients has been reported by Thier, Fox, Segal, and Rosenberg (17). In addition, L-lysine and L-cystine were found to be mutually inhibitory in studies performed with intestinal mucosa from normal subjects.

\section{References}

1. Dent, C. E., B. Senior, and J. M. Walshe. The pathogenesis of cystinuria. II. Polarographic studies of the metabolism of sulphur-containing amino-acids. J. clin. Invest. 1954, 33, 1216.

2. Yeh, H. L., W. Frankl, M. S. Dunn, P. Parker, B. Hughes, and P. György. The urinary excretion of amino acids by a cystinuric subject. Amer. J. med. Sci. 1947, 214, 507.

3. Stein, W. H. Excretion of amino acids in cystinuria. Proc. Soc. exp. Biol. (N. Y.) 1951, 78, 705.

4. Harris, H., U. Mittwoch, E. B. Robson, and F. L. Warren. The pattern of amino acid excretion in cystinuria. Ann. hum. Genet. 1955, 19, 196.

5. Robson, E. B., and G. A. Rose. The effect of intravenous lysine on the renal clearances of cystine, arginine, and ornithine in normal subjects, in patients with cystinuria and Fanconi syndrome and in their relatives. Clin. Sci. 1957, 16, 75.
6. Arrow, V. K., and R. G. Westall. Amino acid clearances in cystinuria. J. Physiol. (Lond.) 1958, $142,141$.

7. Milne, M. D., A. M. Asatoor, K. D. G. Edwards, and L. W. Loughridge. The intestinal absorption defect in cystinuria. Gut 1961, 2, 323.

8. Asatoor, A. M., B. W. Lacey, D. R. London, and M. D. Milne. Amino acid metabolism in cystinuria. Clin. Sci. 1962, 23, 285.

9. Flick, A. L., W. E. Quinton, and C. E. Rubin. A peroral hydraulic biopsy tube for multiple sampling at any level of the gastrointestinal tract. Gastroenterology 1961, 40, 120.

10. Long, C. Biochemist's Handbook. Princeton, N. J., D. Van Nostrand, 1961, p. 675.

11. $\mathrm{Li}, \mathrm{J}$. C. R. Introduction to Statistical Inference. Ann Arbor, Mich., Edwards Bros., 1957, p. 129.

12. Frimpter, G. W., M. Horwith, E. Furth, R. E. Fellows, and D. D. Thompson. Inulin and endogenous amino acid renal clearances in cystinuria: evidence for tubular secretion. J. clin. Invest. 1962, 41, 281.

13. Hagihira, H., E. C. C. Lin, A. H. Samiy, and T. H. Wilson. Active transport of lysine, ornithine, arginine, and cystine by the intestine. Biochem. biophys. Res. Commun. 1961, 4, 478.

14. Neil, M. W. The absorption of cystine and cysteine from rat small intestine. Biochem. J. 1959, 71, 118.

15. Finch, L. R., and F. J. R. Hird. The uptake of amino acids by isolated segments of rat intestine. I. A survey of factors affecting the measurement of uptake. Biochim. biophys. Acta (Amst.) 1960, 43, 268.

16. Colliss, J. E., A. J. Levi, and M. D. Milne. Stature and nutrition in cystinuria and Hartnup disease. Brit. med. J. 1963, 1, 590.

17. Thier, S., M. Fox, S. Segal, and L. E. Rosenberg. Cystinuria: in vitro demonstration of an intestinal transport defect. Science 1964, 143, 482.

\section{SPECIAL NOTICE TO SUBSCRIBERS}

Post Offices will no longer forward the Journal when you move.

Please notify The Journal of Clinical Investigation, Business Office, 10 Stoughton Street, Boston, Mass. 02118, at once when you have a change of address, and do not omit the Zip Code number. 